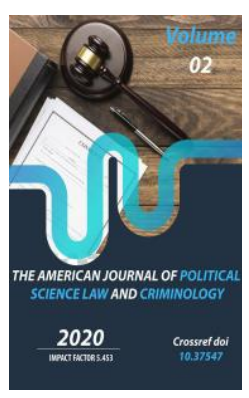

\title{
Difficulties In Teaching Law Students Listening Comprehension In English Language Teaching
}

\author{
Manzura Shamsitdinova \\ Assistant Professor, Foreign Languages Department Tashkent State University Of Law, \\ Tashkent, Uzbekistan
}

Copyright: Original

content from this work may be used under the terms of the creative commons attributes 4.0 licence.

\section{ABSTRACT}

This article discusses the challenges of teaching English listening comprehension to law students and how to overcome them. Law students face some language challenges due to the nature of the English language. That is, students in the early stages of learning are the first to experience the ability to listen and understand. Therefore, it is worth considering the learning difficulties that may arise from the nature of the English language in terms of listening skills. In this article, we want to look at the most common, basic difficulties in listening to and understanding English speech. Although getting acquainted with the difficulties of listening to a speech can increase your preparedness for the confusion and misunderstandings that can occur in the learning process, we would like to draw your attention to the following difficulties mentioned by most law students.

\section{KEYWORDS}

Law students, English language, UNESCO, UNICEF, Action Strategy, comprehensive goal, listening, reading, teaching materials, law students.

\section{INTRODUCTION}

One of the current issues is to educate the younger generation in the spirit of love and devotion to the motherland, national pride, high morals and spirituality, pride in our ancient and rich heritage, national and universal values through the teaching of foreign languages. 
Radical reforms in the global education system raise the problem of creating the necessary conditions for students to learn foreign languages perfectly, to express themselves in all areas with knowledge of a foreign language, to develop their oral and written speech in a foreign language. Organizations such as UNESCO, UNICEF, the European Association of Universities and the European Network for Quality in Higher Education are involved in the development of students' thinking in a foreign language, their ability to speak fluently, the formation of intellectual activity and the assessment of their readiness used. The development of these issues in general trends plays an important role in the formation of modern and foreign language skills in the younger generation and serves to increase the creative abilities of students in connection with the problems of modern education.

When reforming the republic's education system, the coordination of curricula in accordance with international standards based on foreign experience has become the basis for improving the system of higher pedagogical education. In the conditions of Uzbekistan, a radical reform of the quality of education based on foreign experience, taking into account our national mentality and traditions, is a requirement of the time. In this regard, the Action Strategy for the five priority areas of development of the Republic of Uzbekistan for 2017-2021 states: "Improving the quality and efficiency of higher education institutions in our country on the basis of the introduction of international standards for quality assessment of education and training. To stimulate research and innovation, to create effective mechanisms for the implementation of scientific and innovative achievements, to improve the quality of training, to create the necessary conditions for the training of qualified specialists in accordance with international standards, each higher education institution to establish close cooperation with educational institutions and develop students' creative abilities, effective use of interactive methods in working with young audiences, to provide them with quality education in a foreign language, to raise the level of higher education to an exemplary level and Improvements have been identified as key objectives" [1].

Therefore, in order to form the ability to read the original literature on the specialty, to participate in oral communication in a foreign language in the process of production of future personnel and finding the necessary information for scientific purposes in the higher education system of the republic classes are being held.

\section{MAIN PART}

Every citizen of the independent Republic of Uzbekistan should be able to read original literature in a foreign language, understand the text and use it in their profession. In addition, he must be able to communicate freely in a foreign language with his interlocutor on a given topic. After all, learning foreign languages is a requirement of the modern globalized world. Thanks to independence, special attention in our country is paid to teaching foreign languages.

Thousands of foreign language teachers have been trained, all conditions have been created for professional development in our country and abroad, multimedia textbooks in English, German, and French electronic resources for learning English have been prepared. The organization of language rooms is a clear proof 
of this. The main goal is to create conditions for the development of international cooperation and dialogue, based on the education of the younger generation in foreign languages and the improvement of the training of specialists who are fluent in these languages. As the famous German scientist Yu.V Von Goethe: "He who does not know foreign languages does not know his own language." For this reason, it is very important not only for specialists in foreign languages, but also for all future students studying in non-linguistic universities, to study foreign languages and be able to communicate freely. There is a proverb among the people: "He who knows the language knows the world." After all, a person who speaks a foreign language will have many opportunities and advantages. One of the main requirements for today's staff is a good knowledge of foreign languages. In the process of training specialists in all areas, it is important to ensure the priority of the education system, including the introduction of new technologies and mechanisms for teaching foreign languages. After all, communication, spiritual and other communication between peoples is expressed in language. Research on teaching a foreign language to students of non-linguistic universities in the world is carried out in the following priority areas: Improving the pedagogical mechanisms of teaching foreign languages to students in accordance with the requirements of the European CEFR; teaching content, educational technologies, strengthening the objectivity of control, the organization of independent learning in the classroom and outside the classroom.

The goals of teaching a foreign language are determined by the needs of society, social order, conditions and politics. The goals of teaching a foreign language depend on the development and progress of society. Teaching a foreign language in higher education has its own goals, and all trainers who teach a foreign language should clarify this in advance. As noted by scientists $O$. Khoshimov and I. Yakubov in the book "Methods of teaching English", "the goals of teaching a foreign language determine the content, means, methods and principles of teaching"'[16].

Given the goals and objectives of teaching English in higher education, they can be divided into 2 groups:

1. Foreign language - universities, institutes, faculties that train specialists in English.

2. Foreign language - non-philological educational institutions that do not train specialists in English.

The goals of teaching English in these two groups are different, and thanks to the training of specialists in English in higher educational institutions of the first group, English is taught deeply and comprehensively, both theoretically and practically. The second group, non-philological institutions, has a comprehensive goal of learning English. The goal is for the student to receive a general education in English and teach him or her to use English in their future work. Partial communication by profession involves the study of words related to their specialty, as well as reading and translating texts. Teaching foreign languages in higher education institutions includes 1) practical or communicative, 2) general education, 3) upbringing, 4) the use of acquired skills and abilities for other purposes. General, educational, and developmental goals occur in 
the pursuit of a communicative goal. Of course, there are several difficulties in teaching English to non-specialists, especially law students. Difficulties in hearing and understanding law students include:

\section{Phonetic difficulties:}

a) Different sounds that are very similar to each other in terms of acoustics (especially if there is no alternative to these translations in the native language):

$>$ Short vowel sounds;

$>$ Whether the consonants sound or not at the end of the word;

b) Receiving images of different expressions;

c) Determine the relationship of meaning groups or words.

\section{Lexical difficulties:}

a) Differentiate by listening to homonyms and homophones;

b) Differentiate the meanings of polysemous words;

c) Comprehension of speech consisting of unfamiliar words.

In this case, the law student will have to guess the translation of the unfamiliar word, or learn the translation according to the context (word formation, suffixes and international stems). Otherwise, you have to ignore all the unfamiliar words and draw conclusions based on the general content of the sentence.

\section{Grammatical difficulties:}

a) The difference between the word order in the native language and the English language; b) Differentiate grammatical homonyms. For example, the word would be used as an auxiliary verb and a modal verb;

c) Distinguish the meanings and adjectives of plural adjectives and auxiliaries. For example, "-ed" ("He used this tool yesterday" and "He used to smoke a lot"), “-(e)s";

d) Understand and distinguish abbreviated forms: - 'd (had, would) I'd let it go (I would, to be, I had may be Different in meaning); - 's (has, is) He's a son (He has or He is it can. It's different in meaning).

When teaching English, it is difficult to teach law students to listen and understand in the same way. To overcome these difficulties, every law student needs to work on themselves and listen to a lot of audio CDs.

\section{RESULTS AND DISCUSSION}

Law students should be able to receive, understand and express ideas in English orally and in writing after graduation. In higher education institutions that do not specialize in languages, the number of teaching hours is indicated in the curricula of these educational institutions. In non-philological educational institutions, foreign languages are taught according to a special curriculum. Since such programs and textbooks for English special non-philological educational institutions have not yet been developed, the teachers of such educational institutions teaching in the Uzbek language use various textbooks and teaching aids, taking into account the specifics of the direction.

The content of training is one of the most important questions of the methodology. At present, the content of teaching a foreign 
language in higher education institutions that do not specialize in languages is defined as the amount of knowledge, materials, exercises and skills that are determined by the goals and objectives of teaching law students. When defining the content of a subject, it is important to keep in mind two general requirements and their relationship.

Nowadays, it involves a radical change in foreign language teaching. It has the following 3 requirements.

1. Raising the scientific level and practicality of teaching foreign languages;

2. Strengthening the educational aspect of the subject of a foreign language;

3. Independent study of a foreign language subject.

The first requirement can be met in two ways.

1) Change the training content.

2) Reconstruction of the methods of teaching foreign languages.

The old method of reconstruction, which is not relevant today, is to improve the education system by removing roads. Raising the scientific level of the methodology of a foreign language is the popularization of advanced experience, the reconstruction of methods based on innovations in linguistics, psychology, pedagogy and psycholinguistics. For foreign language teaching to be practical, a law student must focus on the ability to independently and competently work on a foreign language. Improving the educational aspect of the subject in a foreign language, teaching meaningful educational texts, newspaper and magazine articles, analyzing socio-political and educational problems, defining the main idea of the text, as well as higher education by grade carried out through extracurricular activities. They educate students in the spirit of patriotism, internationalism, friendship and expand their worldview.

Another way to meet the requirements of modern law is to reduce the amount of excess material for students, to simplify the educational process. They are included in the new foreign language learning program. The teacher approaches this from the point of view of comprehensive practical assimilation of the material by students. For this reason, the student focuses on productive (speaking, writing) and receptive (listening, reading) teaching materials, expanding the potential of the students. The basis of a healthy education is effective generalization and improvement of the educational process. More recently, optimization has become widespread. Optimization is the search and application of a simple and convenient method, method, method, system, principle, tool and exercise that is suitable for the situation, conditions, university students and their chosen field of study. Optimization is typical for different types of higher education institutions, since the hours of classes differ, and the characteristics of the native language of students differ. Currently, communication skills, the ability to provide information in a foreign language (through speaking, writing ideas) and the acquisition of information (through reading, listening comprehension) for the further development of skills and abilities, along with education and upbringing, requires carrying.

\section{CONCLUSION}

In short, it is very important to teach a foreign language in higher education institutions that 
do not specialize in languages, because foreign languages play an important role in preparing students for full-fledged development. Education is not just a teacher-led process. It is closely linked to the activities of law students. In English classes, law students can control their speech, identify and correct mistakes, draw conclusions independently, participate in partial research and creative assignments, which give good results in learning English.

\section{REFERENCES}

1. Decree of the President of the Republic of Uzbekistan. On the Action Strategy for the further development of the Republic of Uzbekistan / Collection of Legislation of the Republic of Uzbekistan, 2017, No. 6, Article 70.

2. English (curriculum for groups of vocational colleges with other languages of instruction). Tashkent: 1999. -p. 29.

3. Mamadaliev AM Didactic bases of language teaching to students of the Pedagogical Institute: Pedagogical science. Abstract of the candidate's dissertation. Tashkent: TDPU, 2000.-p. 23.

4. Nabieva K. Linguopsychological bases of modern foreign language teaching. Problems of philology. 2003. Issue 2. p. 53.

5. Saydaliev S.S. Essays on foreign language teaching methods. Namangan: NamSU, 2000. -p. 210.

6. Sattorov T. Q. Technology of formation of methodical competence of the future foreign language teacher. Tashkent: TDYul, 2003. -p. 191.
7. Sattorov T. Q. Features of a foreign language subject // Public education. 2000. -№ 5. -pp.71-73.

8. The concept of continuing education in a foreign language. Approved by the decision of the regular meeting of the Ministry of Public Education of the Republic of Uzbekistan No. 5G`6. Tashkent: May 14, 1993.

9. Problems of modern technology of teaching foreign languages: Materials of the Republican scientific-methodical conference. Tashkent: TDPU, 2007. -p. 260.

10. Choriev M. Linguodidactic and engineering-linguistic bases of teaching English lexicon: Pedagogical science. Abstract of the candidate's dissertation. Tashkent: 1994. -p. 22.

11. Hoshimov O., Yakubov I. Methods of teaching English. $-\mathrm{T}$.: Sharq, 2003. -p. 302.

12. Adams V. S., Zimmer B. E. Understanding Psychology. -New York: McGraw-Hill Inc., 1990. -p. 296.

13. Hoshimov O., Yakubov I. Methods of teaching English. -T .: Sharq, 2003. -p. 302.

14. Brumft C. Communicative Methodology in Language Teaching. -Cambridge University Press, 1992. -p. 166.

15. Celce-Muricia, M. (Ed.) Teaching English as a Second or Foreign language.-Massachusetts: Heinle Publishers, 1991. -p. 270.

16. Karshiyeva T. The purpose of teaching foreign languages in non-linguistic educational institutions. In this article it was clarified the purpose of teaching 
foreign languages in non-linguistic educational institutions.

17. Shamsitdinova, M. G. (2020). INTERCULTURAL COMMUNICATION AND PROBLEMS OF TEACHING ENGLISH TO THE STUDENTSNONLINGUISTS. Theoretical \& Applied Science, (4), 1024-1026.

18. Salakhova, E., Shamsitdinova, M., \& Shakhakimova, M. (2020). THE IMPACT OF INFORMATION TECHNOLOGIES ON DISTANCE EDUCATION DURING PANDEMIC IN THE REPUBLIC OF UZBEKISTAN. PalArch's Journal of Archaeology of Egypt/Egyptology, 17(6), 8962-8967.

19. Shamsitdinova, M. (2020). Implementation of IT and ICT into education: Multimedia Technologies in Creating and Using Electronic Books. ISJ Theoretical \& Applied Science, 11 (91), 5-10.

20. Salakhova, E. Z., \& Shamsitdinova, M. G. (2020). ADVANCED PEDOGOGICAL TECHNOLOGIES IN EDUCATION IN THE 21-ST CENTURY. Theoretical \& Applied Science, (5), 743-746.

21. Rustamiy, S. (2019). ON SIGNIFICANCE OF SCIENCE OF BALĀĞAT IN ACHIEVING LINGUISTICAESTHETIC PERFECTION. The Light of Islam, 2019(4), 14.

22. Rustamiy, S. A. (2019). Poetical art of Yusuf Balasagun. ISJ Theoretical \& Applied Science, 9(77), 256-259.

23. Rustamiy, S. (2020). MAHMUD KOSHGARIY'S VIEWS ON FONETIC, GRAPHIC AND MORPHOLOGICAL CHARACTERISTICS OF TURKIC LANGUAGES. The Light of Islam, 2020(2), 37-44.
24. Rustamiy, S. A. (2020). Content of components of the science balagat. ACADEMICIA: An International Multidisciplinary Research Journal, 10(10), 1332-1337.

25. Shamsitdinova, M. (2020). Implementation of IT and ICT into education: Multimedia Technologies in Creating and Using Electronic Books. ISJ Theoretical \& Applied Science, 11 (91), 5-10.

26. Shamsitdinova, M., \& Salakhova, E. (2019, February). METHODOLOGICAL AND LINGUISTIC BASES FOR INTERGRATING FOR SKILLS. In International Scientific and Practical Conference" Innovative ideas of modern youth in science and education" (pp. 277-278).

27. Shamsitdinova, M. (2018). Methodological and linguistic bases for intergrating the four skills. Review of law sciences, 2(4), 25.

28. Salakhova, E. Z., \& Shamsitdinova, M. G. ENGLISH FOR LAW STUDENTS.

29. Salakhova, E., Shamsitdinova, M., \& Shakhakimova, M. (2020). THE IMPACT OF INFORMATION TECHNOLOGIES ON DISTANCE EDUCATION DURING PANDEMIC IN THE REPUBLIC OF UZBEKISTAN. PalArch's Journal of Archaeology of Egypt/Egyptology, 17(6), 8962-8967.

30. Odilov, B. A., \& Karimov, N. R. (2020). ANALYSIS OF TARGETED RESEARCH IN 20-30 YEARS OF THE XX CENTURY. PalArch's Journal of Archaeology of Egypt/Egyptology, 17(6), 8887-8893.

31. Rustamiy, S. A. (2020). Lexical Parallels Used In The Quatrains In The Dīwān Lughāt Al-Turk. European Journal of 
The American Journal of Political Science Law and Criminology (ISSN - 2693-0803)

Published: January 06, 2021 | Pages: 1-8

Doi: https://doi.org/10.37547/tajpslc/Volumeo3Issue01-01

Molecular \& Clinical Medicine, 7(3), 5301-5305.

32. Ametova, O. R., \& Mustafoeva, N. I. (2020). The benefits and drawbacks of online education for law students in higher educational institutions. ISJ Theoretical \& Applied Science, 12 (92), 61-63. 